\author{
Anna Czekaj \\ Uniwersytet Śląski w Katowicach
}

\title{
KONSTRUKCJE METONIMICZNE W TŁUMACZENIU AUTOMATYCZNYM
}

DOI: http://dx.doi.org/10.12775/RP.2015.003

\begin{abstract}
Zarys treści: W artykule poruszono problem automatycznego tłumaczenia wyrażeń metonimicznych. Autorka nie koncentruje się zatem na zagadnieniach definicji, typologii ani kryteriów wyodrębniania konstrukcji metonimicznych, gdyż zadaniem translatora automatycznego jest prawidłowe przetłumaczenie danego wyrażenia na język docelowy bez względu na to, jaka jest jego definicja. Posługując się wybranymi przykładami różnych konstrukcji metonimicznych, autorka przedstawia, w jaki sposób proponuje rozwiązać problem ich prawidłowego tłumaczenia podejście zorientowane obiektowo autorstwa W. Banysia.
\end{abstract}

Słowa kluczowe: metonimia, tłumaczenie automatyczne, konstrukcje metonimiczne

J ak wiadomo, metonimia jest zjawiskiem występującym powszechnie we wszystkich typach tekstów. Każdy z użytkowników języka posługuje się na co dzień wieloma konstrukcjami metonimicznymi, najczęściej nie zdając sobie sprawy z tego, że wyrażenie, którego użył, jest określane w językoznawstwie jako metonimia. Nikt nie zastanawia się przecież nad tym, że wypowiadając np. zdanie Bardzo lubię Sienkiewicza, używa konstrukcji metonimicznej, w tym przypadku opartej na relacji 'dzieło zamiast autora', tak oczywiste jest dla niego to, że mówi tak naprawdę o utworach Sienkiewicza, nie zaś o samym autorze. Taka kondensacja treści - uproszczenie wypowiedzi - polegająca na tym, że możemy zastąpić nazwę właściwą A za pomocą nazwy (często krótszej) B, przyczynia się w oczywisty sposób do znacznej ekonomii w języku, co w połączeniu z uniwersalnością związków między obiema nazwami sprawia, że metonimia jest bardzo produktywnym sposobem opisu rzeczywistości. Nie dziwi zatem fakt, że wielu językoznawców poświęca jej 
sporo uwagi w swoich publikacjach, starając się m.in. dokonać szczegółowej klasyfikacji konstrukcji metonimicznych, czy też wytyczyć granice między metonimią a metaforą (zob. Le Guner 1973; Kleiber 1994; Bonhomme 2006; Massoussi 2008). Nasza wypowiedź nie koncentruje się jednak na definicji, typologii ani kryteriach wyodrębniania konstrukcji metonimicznych, gdyż niezależnie od przyjętego podejścia zadaniem translatora automatycznego jest prawidłowe przetłumaczenie danego wyrażenia na język docelowy, bez względu na to, do jakiej kategorii ono należy i jaka jest jego definicja. Posługując się wybranymi przykładami różnych konstrukcji metonimicznych, chcielibyśmy przedstawić, w jaki sposób rozwiązuje problem ich prawidłowego tłumaczenia podejście zorientowane obiektowo W. Banysia. Zanim jednak przejdziemy do omówienia konkretnych przykładów, postaramy się pokrótce przypomnieć główne założenia tego podejścia (zob. Banyś 2002a, 2002b, 2005).

Koncepcja zorientowana obiektowo została stworzona m.in. z myślą o automatycznym tłumaczeniu tekstów, a zatem stawia sobie za cel taki opis słownictwa, który można by w prosty sposób przełożyć na język programowania komputerowego i który gwarantowałby prawidłowe tłumaczenie na język docelowy. Proponowany opis koncentruje się przede wszystkim na poziomie semantycznym, który niewątpliwie przysparza najwięcej trudności tłumaczeniowych, wynikających z polisemicznego charakteru większości słów języka naturalnego.

Jak wiadomo, to, co decyduje o jakości tłumaczenia maszynowego, to sposób opisu i uporządkowania jednostek leksykalnych w bazie danych komputera. Niestety w wielu przypadkach opis ten jest niepełny i nieodpowiedni, skutkujący przez to złym tłumaczeniem, o czym można się łatwo przekonać przy próbie skorzystania $\mathrm{z}$ automatycznych translatorów dostępnych on-line.

W ujęciu zorientowanym obiektowo punktem wyjścia w opisie znaczenia jest obiekt (czyli jednostka leksykalna), charakteryzowany za pomocą wszystkich specyficznych mu cech oraz operacji, jakie może on wykonywać lub jakie mogą być wykonywane na nim. Trzeba przy tym podkreślić, że tego typu informacji o opisywanym obiekcie należy szukać w samym języku, nie zaś w źródłach wiedzy ontologicznej, która, stanowiąc jedynie jakiś wzorzec (prototyp) (dla) danego obiektu, nie zapewnia kompletnych danych potrzebnych do prawidłowego tłumaczenia. To język jest tutaj jedyną wyrocznią decydującą o tym, jakie cechy (rozumiane w kategoriach atrybutów i operacji) przypisujemy danemu obiektowi. Cechy te, stanowiąc zazwyczaj bezpośrednie sąsiedztwo opisywanego słowa, w najbardziej wyczerpujący sposób definiują jego znaczenie, w myśl zasady przyjętej przez autora koncepcji „dis- 
-moi, mon mot, quelle est ta compagnie, je te dirai qui tu es"1 (Grigowicz 2004: 28; zob. Banyś 2002a).

W ten sposób opis jednostek leksykalnych i, w konsekwencji, opis rzeczywistości, jaki otrzymujemy, jest opisem świata widzianego przez pryzmat języka, czyli takiego, jaki jawi się w języku, za pomocą którego przedstawiamy to, co widzimy i czego doświadczamy. Warto przy tej okazji również wspomnieć, że mając na uwadze jak najbardziej kompletny opis słownictwa, metoda zorientowana obiektowo korzysta $\mathrm{z}$ różnych elektronicznych baz danych leksykalnych, korpusów językowych, które stanowią niezwykle bogate źródło kontekstów, w jakich opisywana jednostka może się pojawiać. (zob. np. glossaNet, frantext, korpus IPI PAN, Vetulani 2012). Podstawową zaletą korpusów jest występowanie jednostek leksykalnych w ich naturalnym kontekście, dzięki czemu proponowane tłumaczenia są zgodne ze sposobem ich funkcjonowania w języku docelowym.

W celu zilustrowania omówionych powyżej mechanizmów opisu słownictwa, posłużmy się przykładem francuskiego rzeczownika omelette, którego znaczenie 'potrawa $\mathrm{z}$ jaj usmażonych w formie placka' (SJP PWN) będzie opisywane przy użyciu następujących atrybutów:

$\begin{array}{lll}\text { OMELETTE (n.f.) } & & \text { OMLET (r.m) } \\ \sim \text { au naturel } & - & \text { omlet bez dodatków } \\ \sim \text { aux champignons } & - & \text { omlet z grzybami } \\ \sim \text { au jambon } & - & \text { omlet z szynką } \\ \sim \text { au sucre } & - & \text { omlet z cukrem } \\ \sim \text { aux fines herbes } & - & \text { omlet z ziołami } \\ \sim \text { aux courgettes } & - & \text { omlet z cukinią } \\ \sim \text { au fromage } & - & \text { omlet z serem } \\ \sim \text { au saumon } & - & \text { omlet z łososiem } \\ \sim \text { à la tomate } & - & \text { omlet z pomidorami } \\ \sim \text { au chocola } & - & \text { omlet z czekoladą } \\ \sim \text { aux épinards } & - & \text { omlet ze szpinakiem } \\ \sim \text { à l'oignon } & - & \text { omlet z cebulą } \\ \sim \text { délicieuse } & - & \text { wyśmienity omlet } \\ \sim \text { succulent } & - & \text { smaczny omlet } \\ \sim \text { à la japonaise } & - & \text { omlet po japońsku } \\ \sim \text { facile à réaliser } & - & \text { omlet łatwy do przygotowania }\end{array}$

1 „Powiedz mi, moje słowo, w jakim towarzystwie się pojawiasz, a powiem ci kim jesteś” (tłumaczenie własne). 
$\sim$ baveuse $\quad-\quad$ niedopieczony omlet

$\sim$ flambée $\quad$ - płonący omlet

$\sim$ simple $\quad-\quad$ prosty omlet

$\sim$ diététique $\quad-\quad$ dietetyczny omlet

$\sim$ cuite à la vapeur _ _ omlet na parze

$\sim$ moelleuse $\quad-\quad$ puszysty omlet

itp.

i operatorów:

\begin{tabular}{|c|c|c|}
\hline faire une & - & zrobić omlet \\
\hline cuire une & - & usmażyć omlet \\
\hline préparer une & - & przygotować omlet \\
\hline brûler l' & - & przypalić omlet \\
\hline retourner l'〜 & - & przewrócić omlet \\
\hline manger l' & - & jeść omlet \\
\hline couper l'〜 & & \\
\hline (en morceaux, en carrés) & - & pokroić omlet (na kawałki, w kostkę) \\
\hline acheter une $\sim$ & - & kupić omlet \\
\hline rouler l' & - & zwinąć omlet \\
\hline garnir l’’ (de/avec) & - & faszerować omlet \\
\hline saupoudrer l' (de/avec) & - & posypać omlet \\
\hline dorer l'〜 & - & przyrumienić omlet na złoty kolor \\
\hline brûle & - & omlet przypala się \\
\hline
\end{tabular}

Każdy z opisywanych w ten sposób obiektów należy do jakiejś klasy obiektowej, czyli do zbioru jednostek leksykalnych opisywanych za pomocą tego samego zestawu atrybutów i operatorów. I tak, omelette, będąc rodzajem naleśnika (crêpe), stanowi pewien podzbiór klasy crêpe, z którą, jako nadrzędną, będzie dzielić pewną liczbę cech wspólnych. Innymi słowy, klasa hiperonimiczna przekazuje klasie niższej wszystkie atrybuty i operatory, które są jej właściwe, co w omawianej koncepcji nosi nazwę dziedziczenia semantycznego. W konsekwencji, wszystko to, co można powiedzieć o naleśniku (crêpe), będzie można też zastosować w odniesieniu do omletu (omelette), jak widać poniżej:
crêpe/omelette aux champignons - naleśnik/omlet z grzybami
crêpe/omelette au jambon — naleśnik/omlet z szynką
crêpe/omelette au sucre _ naleśnik/omlet z cukrem
crêpe/omelette aux fines herbes - naleśnik/omlet z ziołami 


\begin{tabular}{|c|c|}
\hline crêpe/omelette au fromage & - naleśnik/omlet z serem \\
\hline crêpe/omelette au saumon & - naleśnik/omlet z łososiem \\
\hline crêpe/omelette au chocolat & - naleśnik/omlet z czekoladą \\
\hline crêpe/omelette aux épinards & - naleśnik/omlet ze szpinakiem \\
\hline crêpe/omelette aux oignons & - naleśnik/omlet z cebulą \\
\hline crêpe/omelette délicieuse & - wyśmienity naleśnik/omlet \\
\hline crêpe/omelette succulente & - smaczny naleśnik/omlet \\
\hline crêpe/omelette à la japonaise & - naleśnik/omlet po japońsku \\
\hline crêpe/omelette facile à réaliser & - naleśnik/omlet łatwy do przygotowania \\
\hline crêpe/omelette flambée & - płonący naleśnik/omlet \\
\hline crêpe/omelette simple & - prosty naleśnik/omlet \\
\hline crêpe/omelette diététique & - dietetyczny naleśnik/omlet \\
\hline crêpe/omelette moelleuse & - puszysty naleśnik/omlet \\
\hline crêpe/omelette soufflée & - puszysty naleśnik/omlet \\
\hline faire une crêpe/omelette & - zrobić naleśnik/omlet \\
\hline cuire une crêpe/omelette & - usmażyć naleśnik/omlet \\
\hline préparer une crêpe/omelette & - przygotować naleśnik/omlet \\
\hline brûler la crêpe/omelette & - przypalić naleśnik/omlet \\
\hline retourner la crêpe/omelette & - przewrócić naleśnik/omlet \\
\hline manger la crêpe/omelette & - jeść naleśnik/omlet \\
\hline \multicolumn{2}{|l|}{ couper la crêpe/omelette } \\
\hline (en morceaux) & - pokroić naleśnik/omlet (na kawałki) \\
\hline acheter une crêpe/omelette & - kupić naleśnik/omlet \\
\hline rouler la crêpe/omelette & - zwinąć naleśnik/omlet \\
\hline garnir la crêpe/omelette & \\
\hline (de/avec) & - faszerować naleśnik/omlet \\
\hline \multicolumn{2}{|l|}{ saupoudrer la crêpe/omelette } \\
\hline (de/avec) & - posypać naleśnik/omlet \\
\hline dorer la crêpe/omelette & - przyrumienić naleśnik/omlet na złoty \\
\hline or & \\
\hline êpe/omelette brûle & - naleśnik/omlet przypala się \\
\hline
\end{tabular}

Klasa obiektowa jest jednym z najważniejszych pojęć prezentowanej metody, w której chodzi nie tyle o szczegółowy opis poszczególnych obiektów (słów), co o opis klas obiektowych, do których mogą one należeć. Nie bez znaczenia jest tu także fakt, że przypisane danej klasie obiektowej atrybuty i operatory są dla niej właściwe tylko w obrębie konkretnego kadru pojęciowego, którym w przypadku opisanego powyżej obiektu omelette jest kuchnia, rozumiana jako sposób przyrządzania potraw. Kadr (frame), rozumiany jako 
pewnego rodzaju statyczny schemat danej sytuacji (zob. Minsky 1975; Banyś 2000), jako pewien prototyp pozwalający ją opisać, jest drugim z kluczowych konceptów ujęcia zorientowanego obiektowo, odgrywającym ważną rolę w tłumaczeniu automatycznym. Sprecyzowanie kadru, w którym pojawia się dane słowo, pozwala bowiem na wydobycie tego, z wszystkich możliwych jego znaczeń, o które w danym kontekście chodzi.

Pojęcie kadru uzasadnia również obecność w schematach opisowych jednostek leksykalnych rubryki Ekstensje, w której umieszczone są wyrażenia (charakteryzujące się najczęściej dużym stopniem skostnienia), gdzie opisywane słowo wykracza poza przyjęty kadr, przez co niemożliwe jest jego dosłowne tłumaczenie na język docelowy. W przypadku jednostki omelette będzie tam umieszczone np. wyrażenie On ne fait pas d'omelette sans casser des oeufs, tłumaczone w języku polskim za pomocą przysłowia Gdzie drwa rąbia tam wióry lecą, które przez swoje znaczenie 'niepożądanych skutków ubocznych, jakie zwykle towarzyszą trudnemu i radykalnemu działaniu' (WSJP) w niczym nie nawiązuje do kadru [sztuki kulinarnej]. Poza ten kadr będzie także wykraczać wyrażenie metonimiczne L'omelette au jambon est partie sans payer ('omlet z szynką wyszedł nie płacąc'), które, użyte w kadrze [restauracja], nie wydaje się dziwne i pozwala się bez problemu zrozumieć, wskazując na konkretnego klienta, który wymienione danie skonsumował. Oczywiście to, że człowiek bez trudu domyśla się z kontekstu sytuacyjnego, w jakim znaczeniu zostało użyte słowo omelette, nie oznacza, że jest to tak samo łatwe dla maszyny, która czerpie informacje wyłącznie ze swojej bazy danych i nie rozumie kontekstu sytuacyjnego. Jednakże, jak pisze Bogucki, przytaczając słowa Champolliona, „komputer nigdy nie zrozumie, ale tłumaczyć może". (Bogucki 2009: 108)

Pytanie, czy komputer poradzi sobie z tłumaczeniem konstrukcji metonimicznych, wydaje się uzasadnione, zważywszy na częstotliwość występowania tego typu wyrażeń w codziennych wypowiedziach. W dalszej części niniejszej wypowiedzi, chcielibyśmy pokazać, w jaki sposób rozwiązuje tego typu problemy (prawidłowego tłumaczenia konstrukcji metonimicznych) metoda zorientowana obiektowo.

Jak można było wcześniej zauważyć, schemat opisowy danej jednostki leksykalnej obejmuje tylko te atrybuty i operacje, które są właściwe dla tej jednostki w danym kadrze konceptualnym. Skutkiem tego opis przytoczonego wyżej obiektu omelette mieszczącego się w kadrze [kuchnia] nie będzie zawierał operacji typu partir (wyjść) - ?*omelette part (omlet wychodzi) - gdyż nie jest to funkcja typowa dla tej klasy obiektów i jako taka w niczym ich nie definiuje. Jeśli zatem komputer nie znajdzie w swojej bazie danych, czyli 
w modelu opisowym obiektu omelette, konstrukcji omelette part, można by przypuszczać, że nie dysponując żadną wskazówką, która pozwoliłaby mu wybrać prawidłowy odpowiednik analizowanego wyrażenia w języku docelowym, wykona tłumaczenie błędne lub też pozostawi nieodnalezione słowo $\mathrm{w}$ wersji oryginalnej (nieprzetłumaczonej). Ujęcie zorientowane obiektowo proponuje, żeby w takich sytuacjach, kiedy program komputerowy nie może zlokalizować jakiejś konstrukcji w danej klasie obiektowej, przetłumaczył ją w sposób dosłowny, co w przypadku wyrażeń metonimicznych, będących naturalnymi skrótami myślowymi, będzie dawało rezultat jak najbardziej poprawny (oczywiście pod warunkiem, że nadawca wypowiedzi jest świadomy tego, w jaki sposób ją konstruuje i co chce powiedzieć).

W efekcie wyrażenie L'omelette au jambon est partie sans payer zostałoby przetłumaczone na język polski jako Omlet z szynka wyszedł nie płacac, co staje się zupełnie zrozumiałe i poprawne, choć tylko przy założeniu, że kontekstem wypowiedzi jest kadr [restauracja], ponieważ tylko w takich okolicznościach powyższa informacja jest czytelna i pozwala się odnieść do rzeczywistej sytuacji (zob. Śmigielska 2011, 2012). Można się oczywiście zastanawiać, czy rzeczywiście kadr [restauracja] jest jedynym kontekstem użycia analizowanego wyrażenia, lecz nawet jeśli tak nie jest i możliwe byłoby wskazanie innych kontekstów, w których pojawiłaby się konstrukcja Omlet $z$ szynka wyszedt nie płacąc, to nie ulega wątpliwości, że [restauracja] jest (proto)typową, czyli najbardziej prawdopodobną sytuacją, w jakiej przytoczone wyżej wyrażenie mogłoby funkcjonować.

Przyjrzyjmy się również np. wyrażeniom:

Lulcère du trois a encore vomi (zob. Kleiber 1999; Haïk 2005). - Wrzód z trójki znów wymiotowat.

Le maillot jaune est en tête. - Źólta koszulka prowadzi,

$\mathrm{w}$ których zastosowanie operacji typu vomir (wymiotować), être en tête (prowadzić) w odniesieniu do rzeczowników ulcère (wrzód) czy maillot (koszulka) daje się uzasadnić tylko ściśle określonym kadrem, jakim (prototypowo) jest w pierwszym przypadku [szpital], a w drugim [wyścig sportowy].

W ten sam sposób można by rozwiązać problem tłumaczenia wielu innych konstrukcji metonimicznych typu:

La salle a sifflé cet acteur. - Sala wygwizdała tego aktora.

Les trains font grève. - Pociagi strajkuja.

Les ceintures noires ont participé aux finales du championnat de France. Czarne pasy brały udział w mistrzostwach Francji itp.

W podanych przykładach niektóre operacje, np. siffler (wygwizdać), mogą być ujęte $\mathrm{w}$ schemacie opisowym danego obiektu, tu: acteur (aktor) 
jako charakterystyczne dla nich i często towarzyszące im w języku, jednakże w przypadku gdy frekwencja użycia danej konstrukcji metonimicznej jest mniejsza, z pewnością nie zostaną one ujęte w opisie. Wtedy właśnie gdy dane wyrażenie nie zostaje wykryte $\mathrm{w}$ grupie operacji właściwych danej klasie obiektowej ani też w kategorii ekstensji, należy pozwolić komputerowi tłumaczyć je dosłownie, co w większości wypadków da efekt prawidłowego, bo najbardziej prawdopodobnego przekładu na język docelowy. Takie podejście, oparte na zasadzie prawdopodobieństwa, pewnie nie zawsze będzie skutkować poprawnym, trafnym tłumaczeniem, jednak będzie skuteczne w większości przypadków, co zważywszy na aktualny stan tłumaczeń automatycznych, jest już niebagatelnym osiągnięciem.

Te właśnie wyrażenia, których dosłowne tłumaczenie nie zawsze daje efekt akceptowalny, stanowią prawdziwą trudność dla komputera. Jest to np. przypadek wyrażenia cheveux longs (długie włosy) użytego w zdaniu On ne recrute pas des cheveux longs dans notre entreprise. Jak można przypuszczać, wyrażenie to na pewno nie należy do kategorii połączeń wyrazowych o wysokim poziomie frazeologizacji, co można potwierdzić posługując się jakimkolwiek testem badającym stopień skostnienia związków wyrazowych, jak np. ten zaproponowany przez Grossa (Gross 1996). Gross proponuje, aby za całkowicie skostniałe uznawać te wyrażenia, których znaczenie nie jest sumą znaczeń poszczególnych wyrazów składowych, w których żaden z elementów nie może zostać wymieniony na inny i w których typowe możliwości składniowe danej kategorii gramatycznej są zablokowane. Dzieje się tak np. w przypadku francuskiego wyrażenia cordon-bleu, którego znaczenia dobrej kucharki nie sposób wydobyć ze znaczeń elementów cordon (sznurek, tasiemka) i bleu (niebieski) i w którym żadna z części składowych nie może zostać zastąpiona jakąś inną. Ponadto przymiotnik bleu nie może w tym wypadku zostać poprzedzony żadnym przysłówkiem - nie można np. powiedzieć ?*cordon très bleu - co jeszcze bardziej świadczy o tym, jak bardzo zwrot ten jest utarty i skostniały. Dużo częstsze są wyrażenia, w których przynajmniej jeden z elementów składowych dopuszcza możliwość wymiany, jak np. w przywołanym przez Grossa przykładzie rater le coche (stracić okazję), w którym czasownik rater (przegapić, stracić) można zastąpić jakimś innym, o podobnym znaczeniu, typu: louper le coche lub manquer le coche (Gross 1996). W tym wypadku, nawet jeśli znaczenia całego wyrażenia nie można odczytać na podstawie znaczeń jego poszczególnych komponentów, istnieje tu pewna dowolność w doborze czasownika.

Powracając do przykładu cheveux longs, można już na pierwszy rzut oka stwierdzić, chociażby na podstawie samego znaczenia, przejrzystego i łatwego 
do odczytania ze znaczeń obu części składowych, że nie jest to konstrukcja podlegająca takim samym restrykcjom semantyczno-składniowym, co wyrażenia przytoczone powyżej. Obserwujemy tu również dużo większą dowolność w wyborze członu określającego, jak np. cheveux courts (włosy krótkie), cheveux en brosse (włosy na jeża), cheveux gras (tłuste włosy), cheveux blonds (włosy blond) itd., a zastosowany przymiotnik (long), jako predykatywny, zachowuje tu wszystkie swoje właściwości kategorialne, jak np. dopuszczalność nominalizacji: la longueur des cheveux (długość włosów), czy możliwość funkcjonowania z przysłówkiem: cheveux très longs (włosy bardzo długie). Jak więc widać, analizowana konstrukcja nie jest utartym związkiem frazeologicznym i nie można jej zatem wpisać do kategorii ekstensji w schemacie opisowym obiektu cheveu. Wszystkie wspomniane wyżej przymiotniki będą natomiast figurować w rubryce atrybutów, ponieważ są to typowe dla tego obiektu cechy, pozwalające go zdefiniować jako włos $(y)$. Co jednak zrobić w wypadku gdy nazwa cheveux longs wcale nie odnosi się do (długich) włosów, lecz wskazuje, przez metonimię, na ich nosiciela, co właśnie pokazuje przykład On ne recrute pas des cheveux longs dans notre entreprise. Każdy z nas potrafiłby oczywiście zinterpretować to zdanie w sposób poprawny, tłumacząc je na język polski jako np. Nasza firma nie zatrudnia długowłosych/mężczyzn z długimi włosami itp. Jak jednak ma sobie z tym poradzić komputer, który w opisie obiektu cheveu znajdzie wyrażenie cheveux longs $\mathrm{z}$ odpowiadającym mu ekwiwalentem polskim długie włosy? Proponowane zwykle w tego typu przypadkach tłumaczenie dosłowne: Nasza firma nie zatrudnia długich włosów, może i będzie zrozumiałe, jednak stopień jego akceptowalności, nawet w ściśle określonym kadrze, będzie na pewno dużo mniejszy niż w przypadku wychodzącego omleta czy wymiotującego wrzodu. Wiadomo, że każdy kadr, jako pewien mikroświat, będzie się charakteryzował jakimiś swoistymi, właściwymi tylko sobie konstrukcjami metonimicznymi, które, usytuowane właśnie w ramach tego kadru, nie będą kłopotliwe do interpretacji, co potwierdzają wymienione wcześniej przykłady. $Z$ tego punktu widzenia zdanie On ne recrute pas des cheveux longs dans notre entreprise jest o tyle trudne dla translatora automatycznego, że usytuowanie go w odpowiednim kadrze i dosłowne przetłumaczenie wciąż nie daje zadowalających rezultatów. W tego typu przypadkach należałoby jeszcze zatem wziąć pod uwagę typy kontekstów, w jakich cheveux longs/courts itp. pojawiają się $\mathrm{w}$ znaczeniu osobowym, i wtedy, na podstawie przeprowadzonych analiz ukazujących możliwe operatory, które towarzyszą temu znaczeniu rzeczownika cheveu, zaproponować odpowiedni sposób tłumaczenia.

Istnieje naturalnie wiele różnych innych konstrukcji metonimicznych, które mogą wydawać się skomplikowane dla translatorów automatycznych. 
Wystarczy choćby przywołać przykład zaczerpnięty z pracy doktorskiej Massoussiego Paul est blanc, w którym przymiotnik blanc może odnosić się, na zasadzie metonimicznej relacji [całość za część] zarówno do koloru skóry, jak i do włosów (zob. Massoussi 2008). W konsekwencji wymieniony przymiotnik należałoby przetłumaczyć na trzy różne sposoby jako biały, blady lub siwy, pomijając jego użycie metaforyczne, które wymagałoby jeszcze innego tłumaczenia, a mianowicie niewinny. W tym jednak przypadku metoda zorientowana obiektowo, będąc modelem semantyczno-syntaktycznym, wykorzystuje informacje natury składniowej, które pozwalają naprowadzić komputer na prawidłowe tłumaczenie (zob. Czekaj 2011). I tak, jeśli przymiotnikowi blanc towarzyszy w zdaniu jakieś porównanie typu blanc comme un cachet d'aspirine, comme linge (blady jak prześcieradło) itp., jego tłumaczenie będzie wymagało użycia polskiego przymiotnika blady. Jeśli natomiast ten sam przymiotnik ma wskazywać na kolor włosów, siwy, w tym wypadku będzie to podkreślone w zdaniu obecnością takich elementów jak przysłówki czasu, np. dziś, teraz oraz informacje dotyczące wieku podmiotu skorelowane z przysłówkiem déjà (już). Dodatkowo, wspomniany sens jest często uwydatniony za pomocą przysłówka tout (całkiem), co ilustrują następujące przykłady (Massoussi 2008: 118; zob. Czekaj 2007):

Paul est (maintenant, aujourd'hui) un homme tout blanc. - Paul jest (teraz, dziś) całkiem siwy.

A 30 ans, Paul est déjà tout blanc. - W wieku 30 lat Paul jest już catkiem siwy.

W pozostałych przypadkach, kiedy w zdaniu nie występują żadne tego typu wyrażenia precyzujące znaczenie analizowanego przymiotnika, jego polskim ekwiwalentem będzie słowo biały. $\mathrm{Z}$ kolei metaforyczne znaczenie przymiotnika blanc (niewinny), podobnie jak we wcześniejszych przypadkach, będzie również zaznaczone porównaniem, tyle że tym razem będzie to porównanie blanc comme neige (czysty jak łza).

Inną grupę konstrukcji metonimicznych stanowią metonimiczne użycia nazw własnych, w których najczęściej widoczne są relacje np.

autor za dzieło, np. Je niai pas lu Balzac. - Nie czytałam Balzaka.

Il écoute du Mozart. - On słucha Mozarta.

marka za produkt, np. J'ai vendu ma Renault. - Sprzedałam swoje renault. miejsce pochodzenia za produkt, np. Vous aurez l'occasion de goûter du Cantal - Będziecie mieli okazję spróbować kantala.

miejsce za instytucję, np. La France a proposé son aide aux Etats-Unis, frappés par l'ouragan Sandy - Francja zaproponowała pomoc Stanom Zjednoczonym dotkniętym huraganem Sandy. 
miejsce za mieszkańców, np. Ce scandale a secoué la Pologne - Ten skandal wstrzasną Polska itd.

Na pierwszy rzut oka wydawałoby się, że wyrażenia tego typu nie będą stanowić dla komputera żadnej trudności translatorskiej, gdyż pojawiające się $\mathrm{w}$ nich nazwy własne są, $\mathrm{z}$ reguły, podawane $\mathrm{w}$ wersji oryginalnej, a zatem nie wymagają tłumaczenia. Tu ewentualne problemy ze zrozumieniem tekstu mogą wynikać bardziej z niedostatecznej wiedzy, jaką dysponuje odbiorca komunikatu niż z niedociągnięć oprogramowania komputerowego. O ile bowiem nazwy takie jak renault, Balzak, Mozart, Francja są dla Polaków zrozumiałe i pozwalają na dobre odczytanie informacji, to już określenia typu un cantal, un kleenex, un sopalin czy też un laguiole przyczyniają się do niezrozumienia treści komunikatu, wywołując nawet pewne rozczarowanie co do jakości programu tłumaczeniowego i wiarygodności tłumaczenia. Nie każdy przecież musi wiedzieć, że pod wymienionymi i egzotycznie brzmiącymi nazwami kryją się zwykłe, codzienne przedmioty, takie jak ser, chusteczki higieniczne, ręczniki papierowe czy noże. Dlatego też ujęcie zorientowane obiektowo proponuje wylistowanie najczęściej pojawiających się, a nic niemówiących polskiemu odbiorcy, nazw własnych wraz z wyjaśnieniem ich metonimicznego znaczenia, aby $\mathrm{w}$ razie natrafienia na konstrukcję typu il faut se servir d'un sopalin, kleenex, laguiole albo Bercy doit trouver 1,5 milliard d’euros supplémentaires komputer mógł znaleźć w swojej bazie danych stosowny odpowiednik polski danej nazwy własnej i zaproponować odpowiednie tłumaczenie: użyć ręcznika papierowego, chusteczki higienicznej, noża lub Ministerstwo Gospodarki i Finansów we Francji musi znaleźć dodatkowych 1,5 miliarda euro.

Innym godnym uwagi problemem jest ten, który można znaleźć choćby w konstrukcji metonimicznej zbudowanej na relacji [konsekwencja zamiast przyczyny], gdzie francuski czasownik refroidir (ochłodzić, oziębić) jest użyty, w języku potocznym, żargonowym, w zastępstwie czasownika assassiner, tuer (zamordować, zabić): „Si tu fais le méchant, si tu cries, si tu appelles au secours [...] je vais te refroidir d'un coup de mon stylet, et je me sauve" (CNRTL). Zastanówmy się jednak, czy w podanym przykładzie na pewno mamy do czynienia z metonimią. Nie bez znaczenia jest tu fakt, że przywołany przykład należy do rejestru żargonowego, co pociąga za sobą dwa różne sposoby rozwiązania problemu poprawnego tłumaczenia. Otóż jeśli traktować żargon jako język „obcy” dla języka ogólnego, to komputer musi wtedy dysponować odpowiednią informacją w swojej bazie danych, precyzującą, że czasownik refroidir ma zostać przetłumaczony jako zabić, a wtedy w przytoczonym zadaniu metonimia $\mathrm{w}$ ogóle się nie pojawia. Jeśli natomiast chcemy opisać właśnie ten 
język „obcy” - żargon pod kątem metonimii, to może się okazać, że czasownik refroidir będzie zwykłym operatorem wpisanym do schematu opisowego klasy obiektowej les humains (ludzie), z przypisanym mu odpowiednikiem $\mathrm{w}$ języku docelowym, tu: zabić. W takim wypadku raczej też trudno byłoby tu mówić o metonimii, która byłaby widoczna wówczas, gdyby rozpatrywany czasownik oznaczał np. oziębić serce, co skutkuje śmiercią. Ponieważ jednak jest to mało prawdopodobne, czasownik refroidir należy tu traktować jako taki sam czasownik jak tuer w języku ogólnym, a zatem nie jako metonimię.

Przedstawione tu przykłady $\mathrm{z}$ całą pewnością nie wyczerpują przeogromnego zasobu konstrukcji metonimicznych, jakich używamy na co dzień i z jakimi w konsekwencji musi się zmierzyć translator automatyczny. Pamiętajmy jednak, że ponieważ żyjemy w erze cyfrowej i ilość informacji, jakie docierają do nas drogą elektroniczną, rośnie w olbrzymim tempie, „automatyzacja procesu przekładu jest obecnie faktem, a jej rola będzie niewątpliwie coraz bardziej znacząca" (Bogucki 2009: 12; zob. Vetulani i in.. 1998; Kozłowski 2004; Mykowiecka 2007). Dlatego też musimy dać do dyspozycji komputerom odpowiednio skonstruowaną bazę danych, czyli taki opis słownictwa, który będzie gwarancją poprawnego tłumaczenia. Mając na uwadze ten cel, chcieliśmy pokazać niektóre konstrukcje, tu akurat metonimiczne, które mogą być skomplikowane dla tłumacza automatycznego i przybliżyć, w jaki sposób proponuje rozwiązać problem ich prawidłowego tłumaczenia podejście zorientowane obiektowo.

\section{Literatura}

Banyś, W., 2000, Système de si en français moderne. Esquisse d'une approche cognitive, Katowice.

Banyś, W., 2002a, „Bases de données lexicales électroniques - une approche orientée objets. Partie I: Questions de modularité", [w:] Neophilologica, nr 15, s. 7-28.

Banyś, W., 2002b, „Bases de données lexicales électroniques - une approche orientée objets Partie II: Questions de description", [w:] Neophilologica, nr 15, s. 206-248.

Banyś, W., 2005, „Désambiguïsation des sens des mots et représentation lexicale du monde", [w:] Neophilologica, nr 17, s. 57-76.

Bartlett, F.C., 1932, Remembering: A Study in Experimental and Social Psycho$\log y$ New York-London.

Bogucki, Ł., 2009, Ttumaczenie wspomagane komputerowo, Warszawa. 
Bonhomme, M., 2006, Le discours métonymique, Bern-Berlin-Bruxelles etc. Czekaj, A., 2011, „Question de métonymie dans la traduction automatique”, [w:] Neophilologica, nr 23, s. 136-149.

Grigowicz, A., 2004, „Parties du corps et approche orientée objets”, [w:] Neophilologica, nr 16, s. 20-41.

Gross, G., 1996, Les expressions figées en français. Les noms composés et autres locutions, Editions Ophrys.

Haï, I., 2005, http://www.crisco.unicaen.fr/IMG/pdf/Metonymiesverbales. pdf, (dostęp: 4 listopada 2013 r.).

Kleiber, G., 1999, „Une métaphore qui ronronne n'est pas toujours un chat heureux", [w:] La métaphore: entre philosophie et rhétorique, N. Charbonnel, G. Kleiber (red.), Paris.

Kleiber, G., 1994, Nominales - essais de sémantique référentielle, Paris.

Kozłowski, S., 2004, „Co to jest tłumaczenie maszynowe ?”, http://kf.mish. uw.edu.pl/kog/kog_seb.pdf, (dostęp: 18 marca 2014 r.).

Le Guern, M., 1973, Sémantique de la métaphore et de la métonymie, Paris.

Massoussi, T., (2008), Mécanisme de la métonymie: approche syntactico sémantique (thèse de doctorat).

Minsky, M., 1975, „A Framework for Representing Knowledge”, [w:] The Psychology of Computer Vision, P.H. Winston (red.), New York, s. 211-277.

Mykowiecka, A., 2007, Inżynieria lingwistyczna. Komputerowe przetwarzanie tekstów w jezzykach naturalnych, Warszawa.

Śmigielska, B., 2011, „Rôle et description du contexte dans la traduction automatique des textes - approche orientée objets", [w:] Romanica Cracoviensia, nr 11, Kraków, s. 422-432.

Śmigielska, B., 2012, „Ujęcie zorientowane obiektowo, klasy obiektowe, kadry i skrypty w tłumaczeniu automatycznym", [w:] Rocznik Przekładoznaw$c z y$, t. 7, s. 121-143.

Vetulani, G., 2012, Kolokacje werbo-nominalne jako samodzielne jednostki języka. Syntaktyczny słownik kolokacji werbo-nominalnych języka polskiego na potrzeby zastosowań informatycznych. Część I, Poznań.

Vetulani, Z. i in., 1998, Dictionary based methods and tools for Language Engineering, Poznań.

\section{Wykaz skrótów}

SJP PWN - Słownik języka polskiego PWN, http://sjp.pwn.pl/slownik/2495246/omlet (dostęp: 29 października 2013 r.).

WSJP - Wielki słownik języka polskiego, http://www.wsjp.pl/index. php?id_hasla=3054 (dostęp: 10 listopada 2013 r.). 
CNRTL - Centre National de Ressources Textuelles et Lexicales, http://www.cnrtl.fr/definition/refroidir (dostęp: 5 listopada 2013 r.).

glossaNet - http://glossa.fltr.ucl.ac.be/?lang=fre (dostęp: 6 listopada 2013 r.).

frantext - http://www.frantext.fr/ (dostęp: 6 listopada 2013 r.).

IPI PAN - Korpus języka polskiego IPI PAN, http://korpus.pl/ (dostęp: 6 listopada 2013 r.).

\section{Metonymic structures in automatic translation}

\section{Summary}

The focal point of this study is to investigate how metonymic expressions can be handled within automatic translation. My aim is not to go into the details of definitions, typologies or criteria for the identification of metonymic expressions as the task of an automatic translator is to provide an appropriate translation of an expression regardless of how it is classified. Using a selection of instances of different metonymic structures, I delineate an approach to proper translation of those structures offered by the object-oriented method developed by W. Banyś.

Kewywords: metonymy, automatic translation, metonymic structures

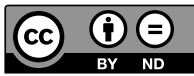

